\title{
Bacterial inhibition test of methanolic extracts of strawberry (Fragraia x ananassa Duchesne), lime (Citrus aurantifolia), and radish (Raphanus sativus L.), towards Streptococcus sanguis ATCC 10556
}

\author{
Fitri Anggraini", Mieke Hemiawati Satari*, "Marry Siti Mariam* \\ *Department of Oral Biology Faculty of Dentistry Universitas Padjadjaran, Indonesia
}

\begin{abstract}
Introduction: Caries are initiated by the plaque formation on the tooth surface, due to the interaction between food debris and bacteria in the mouth. The pioneer bacterium of plaque formation is Streptococcus sanguis. The strawberry fruit, lime fruit, and radish root are part of the plant that contains antibacterial substances. Flavonoid, tannin, saponin, alkaloid, polyphenol, terpenoid and quinon as antibacterial substances. This study was aimed to evaluate strawberry fruit, lime fruit, and radish root methanol extract can inhibit Streptococcus sanguis ATCC 10556. Therefore, strawberry, lime, and radish can be made into mouthwash, bubble gum, or toothpaste to prevent plaque formation. Methods: This study was using a Kirby-Bauer diffusion test as the inhibition test. Results: The result of this study that the biggest inhibition zone was lime methanol extract 20,000 ppm, and the smallest one was radish methanol extract $5,000 \mathrm{ppm}$. Conclusion: Strawberry fruit, lime fruit peel, and radish root methanol extract and their combination had the effect of inhibiting bacterial growth synergistically against Streptococcus sanguis ATCC 10556.
\end{abstract}

Keywords: Citrus aurantifolia, Fragaria x ananassa Duchesne, inhibition test, lime, radish, Raphanus sativus $L$, strawberry, Streptococcus sanguis.

p-ISSN: 1979-0201; e-ISSN: 2549-6212; Available from: http://jurnal.unpad.ac.id/pjd/editor/submission/18325

DOI: http://dx.doi.org/10.24198/pid.vol30no2.18325

Submission: Nov 11, 2017; Accepted: Apr 13, 2018; Published online: July 31, 2018

\section{INTRODUCTION}

The most encountered dental health problem is teeth caries. Nearly every individual in Indonesia has caries. ${ }^{1}$ According to Indonesian Basic Health Research (Riskesdas) in 2013, caries prevalence in Indonesia was $46.5 \%$ and $72.1 \%$. Caries is a progressive dental disease, developed from bacterial carbohydrate fermenting activity in plaque biofilm on teeth surface. Initially, caries is formed by plaque biofilm due to acquired pellicle and bacterial colony interaction on enamel surface until the bacteria co-aggregated. ${ }^{2,3}$ Facultative anaerobic gram positive bacteria such as Actinomyces viscous and Streptococcus sanguis is the dominant pioneer bacteria

\#Corresponding author: Marry Siti Mariam, Department of Oral Biology, Faculty of Dentistry, Universitas Padjadjaran, Indonesia

Sekeloa Selatan I, Bandung 40132, Indonesia. Phone: +62 819-0508-8875. E-mail: marry.mariam@fkg.unpad.ac.id 
adhere to pellicle and formed plaque biofilm. ${ }^{4}$

Plaque biofilm process can be interrupted by doing plaque control. ${ }^{4}$ Mechanically, it can be done with brushing and chemically with mouthwash containing antibacterial agent, either synthetic chemical or natural..,4 Recently, people take interest in utilizing natural substance as there is no adverse effect of long term use as it is in synthetic chemical. Some of the natural substances we can utilize are strawberry, lime, and radish.

Strawberry fruit (Fragaria $x$ ananassa Duchesne) has a lot of advantages as antioxidant, antibacterial, antivirus, diuretic, preventing cataract, protecting from abnormal cell growth and free radical, and preventing caries. ${ }^{5-7}$ It has flavonoid active agent as antibacterial, denaturing bacterial protein. ${ }^{8}$ Besides, study reported that strawberry can inhibit bacterial growth with MIC at $12.5 \%$ concentration. ${ }^{7}$

In dentistry, lime fruit (Citrus aurantifolia) is used to whiten teeth, clean nicotine plaque, and reduce plaque score. ${ }^{7-11}$ It has antibacterial properties due to essential oil content consisting of active agent : flavonoid, polyphenol, and saponin. ${ }^{12}$ These compounds can denature bacterial proteins thereby inhibiting bacterial growth. Recent study showed that lime fruit peel can inhibit MRSA (Methicillin Resistant Staphylococcus aureus). ${ }^{13}$

Radish (Raphanus sativus L) has plenty benefits, used to deal insomnia, pharyngitis, sinusitis, heartcirrhosis, as a diuretic, antibacterial, and toxin detoxification. ${ }^{7}$ Radish roots and leaves contain active agents such as flavonoid, polyphenol, and saponin. Recent study conducted by Takaya et al. in 2009 revealed that radish has antibacterial substances which can inhibit $E$. coli growth. ${ }^{14}$

Antibacterial agents in strawberry, lime, and radish are expected to be utilized as a teeth plaque formation inhibitor. It can be made into different forms: mouthwash, gum, or dentifrice. This study is conducted to evaluate how strawberry fruit, lime fruit and radish root extract and their combination in inhibiting Streptococcus sanguis ATCC 10556.

Inhibition test using combination of three extract purpose was to know whether the combination interacted and affected antibacterial effect. Interaction result can be synergist or antagonist, both is pharmacodynamic interaction. Synergist effect is the effect which cause one substance enhances the other, while antagonist is the effect which cause one substance nullifies the other. ${ }^{15}$

\section{METHODS}

Method used in this study was Kirby Bauer with two repetitions and bacterial number was adjusted according to McFarland standard 0.5. Extracts concentration tested made adjusted to 1,000 ppm, 5,000 ppm, 10,000 ppm, and 20,000 ppm.

Extracts were made with maceration method using $1 \mathrm{~kg}$ of strawberry fruit, lime fruit peel, and radish. It was done for 72 hours at room temperature. Extract was stored in sterile bottle at freezer temperature. Then, it was dissolved in DMSO (dimethyl sulphoxide) to achieve desired concentration.

Subcultured and standardized bateria in Muller Hinton Broth medium was moved by swabbing it to Muller Hinton Agar (MHA) medium. Each medium filled with the extract and DMSO as a negative control. Medium was incubated for $24-48$ hours at $37^{\circ} \mathrm{C}$ in anaerobic facultative environment. Inhibition zone was measured using caliper.

\section{RESULTS}

Initial test of the antibacterial activity of $100 \%$ exract of strawberry fruit, lime fruit peel, and radish root, showed that inhibition was marked with clear area as inhibition zone around medium. Inhibition zone diameter measurement at 20,000 ppm, 10,000 ppm, 5,000 ppm, and 1,000 ppm concentration in strawberry extract as well as lime fruit peel extract and radish root extract showed the smaller the concentration, the smaller the inhibition zone formed (Table 2). Combination of strawberry fruit, lime fruit peel, and radish root extract showed a synergist and antagonist effect, which was marked with an increase and decrease of inhibition zone diameter compared with the previous test (Table 2).

\section{DISCUSSION}

Phytochemical screening showed that strawberry has alkaloid, polyphenol, tanin, and quinon. ${ }^{16}$ Lime contains alkaloid, phenol, flavonoid, saponin, and terpenoid. ${ }^{12}$ Radish has polyphenol, flavonoid, and 
Table 1. Inhibition zone measurement of strawberry fruit, lime fruit peel, and radish roots methanol extract against Streptococcus sanguis ATCC 10556 at 100\% concentration

\begin{tabular}{cc}
\hline \multirow{2}{*}{ Methanol extract (100\%) } & Inhibitory zone $(\mathrm{mm})$ \\
\cline { 2 - 2 } & $100 \%$ \\
\hline Strawberry fruit & 28.7 \\
Lime peel fruit & 40.5 \\
Radish root & 15.0 \\
\hline
\end{tabular}

Table 2. Inhibition zone measurement of strawberry fruit, lime fruit peel, and radish roots methanol extract against Streptococcus sanguis ATCC 10556 at 100\% concentration

\begin{tabular}{cccccc}
\hline \multirow{2}{*}{ Methanol extract } & \multicolumn{5}{c}{ Mean of inhibitory zone $(\mathrm{mm})$} \\
\cline { 2 - 6 } & $\mathbf{2 0 , 0 0 0} \mathrm{ppm}$ & $\mathbf{1 0 , 0 0 0} \mathrm{ppm}$ & $\mathbf{5 , 0 0 0} \mathrm{ppm}$ & $\mathbf{1 , 0 0 0} \mathrm{ppm}$ & Control (-) \\
\hline Strawberry fruit & 27.465 & 26.935 & 23.35 & 0 & 0 \\
Lime fruit peel & 28.8 & 25.385 & 17.9 & 0 & 0 \\
Radish root & 22.7 & 19.485 & 18.35 & 0 & 0 \\
\hline
\end{tabular}

Table 3. The effect of strawberry methanol, lime methanol, and radish methanol extract combination on inhibition diameter zone average against Streptococcus sanguis ATCC 10556

\begin{tabular}{cccccc}
\hline \multirow{2}{*}{ Combination Methanol Extract } & \multicolumn{5}{c}{ Mean of inhibitory zone } \\
\cline { 2 - 6 } & $\mathbf{2 0 , 0 0 0} \mathrm{ppm}$ & $\mathbf{1 0 , 0 0 0} \mathrm{ppm}$ & $\mathbf{5 , 0 0 0} \mathrm{ppm}$ & $\mathbf{1 , 0 0 0} \mathrm{ppm}$ & Control (-) \\
\hline Strawberry - Lime & 26.75 & 22.915 & 20.75 & 17.15 & 0 \\
Strawberry - Radish & 18.25 & 17.63 & 16.97 & 0 & 0 \\
Radish - Lime & 26.57 & 19.2 & 18.02 & 17.23 & 0 \\
Strawberry - Lime - Radish & 26.735 & 24.75 & 20.55 & 0 & 0 \\
\hline
\end{tabular}

saponin. ${ }^{17}$

Alkaloid in strawberry fruit and lime fruit peel can inhibit bacterial growth by inhibit peptidoglican formation hence, cell wall was not intact and leads to cell death. Nitrogen in alkaloid will react with amino acid which forms cell wall and bacteria DNA, thus DNA balance is impaired and leads to bacterial lysis. ${ }^{8}$

Flavonoid and phenol in strawberry, lime, and radish, as well as terpenoid in lime denaturate bacterial protein and form hydrogen bond with protein damaging the protein structure. It leads to decreasing of cell wall and cytoplasm membrane permeability, furthermore creates macromolecule and micromolecule imbalance and cell lysis. Phenol, flavonoid, and terpenoid are either bactericidal or bacteriostatic depends on concentration given. Flavonoid also forms a nucleate acid-base bond which caused bacteria inhibition of DNA/RNA synthesis and metabolism. ${ }^{18,19}$
Saponin in lime and radish can lower cytoplasm membrane surface tension, making the nutrient and other substances cannot through inside the cell. Thus, bacteria cell metabolism is inhibited and ATP is decreased. It will make bacteria growth and development is disturbed. Last, tanin and quinon in strawberry will inhibit bacterial growth in similar way. It will inactivate bacterial adhesin, interrupt bacterial enzyme function and protein transport in cell layer. ${ }^{20}$

Recent study revealed that both extract has antibacterial effect, showed by clear zone around medium. The biggest inhibition zone diameter average is resulted by lime methanol extract (Table 1). Inhibition zone diameter size formed by lime methanol extract because of more light texture compared with the others. Besides, antibacterial compound in lime methanol extract is various and it can work optimally to inhibit bacterial growth. Therefore, the inhibition zone is bigger. 
Inhibition zone diameter measurement result showed that the smaller the concentration given, the smaller the inhibition diameter zone formed (Table 2). It is in agreement with existing theory that concentration change in a drug will caused change in response or drug effect. ${ }^{15,21}$ Extract with small concentration has a small amount of antibacterial substance; hence it cannot inhibit bacterial growth optimally.

Lime fruit peel and strawberry fruit extract formed relatively big inhibition zone and radish root extract formed a relatively small inhibition zone (Table 2). For example in 20000 ppm concentration, inhibition zone formed by radish root was $22.7 \mathrm{~mm}$, strawberry fruit $27.465 \mathrm{~mm}$, and lime fruit peel $28.8 \mathrm{~mm}$. It can be caused of texture difference, radish had the most viscous texture and lime had the most light texture. Extract texture affected diffusion into the agar medium, thus the bacteria inhibition distance was restricted. It is in agreement with existing theory that inhibition zone diameter size is affected by agent ability to diffuse, the worse the agent solubility, the smaller the inhibition zone formed compared with more soluble agent. ${ }^{22}$

All three extracts at $1000 \mathrm{ppm}$ concentration showed no inhibition zone formed however, combination of strawberry fruit and lime fruit peel extract and lime and radish methanol extract at $1000 \mathrm{ppm}$ concentration showed inhibition zone formed. It implies that particular substances in the extract alone at $1000 \mathrm{ppm}$ concentration not show antibacterial effect except combined. Inhibition ability at $1000 \mathrm{ppm}$ concentration was rise with relation of lime fruit peel extract combination. It means that particular substance in lime is the most dominant.

Other than that, antibacterial effects become more vary if combined, mainly radish root methanol extract which have only 3 antibacterial agents alone. However, in this study combination of the three extract at $1000 \mathrm{ppm}$ concentration couldn't inhibit bacteria growth due to antibacterial effect at $1000 \mathrm{ppm}$ concentration of each extract may be was too small to work optimally.

Size of inhibition zone formed from extract combination can be affected by solution diffuse factor to MHA medium. Viscous extract in certain concentration combined with light extract at the same concentration will improve viscous extract diffuse ability to MHA medium yet decrease light extract ability to diffuse to MHA medium. ${ }^{23}$

\section{CONCLUSION}

Strawberry fruit, lime fruit peel, and radish root methanol extract and their combination had the effect of inhibiting bacterial growth synergistically against Streptococcus sanguis ATCC 10556.

\section{REFERENCES}

1. Kurniawan A, Andang MA, Hayati AT. The effect of Beetle leaves (Piper Betle Linn) for dental caries formation. Padjadjaran J Dent. 2007; 19(3): 166-72. DOI: 10.24198/pjd. vol19no3.14162

2. Banerjee A, Watson TF. Pickard's Manual of Operative Dentistry. 9th ed. Oxford: Oxford University Pres Inc; 2011. p. 1-6.

3. Percival RS, Devine DA, Duggal MS, Chartron S, Marsh PD. The effect of cocoa polyphenols on the growth, metabolism, and biofilm formation by Streptococcus mutans and Streptococcus sanguinis. Eur J Oral Sci. 2006; 114(4): 343-8. DOI: $10.1111 / j .1600-0722.2006 .00386 . x$

4. Newman M, Takei H, Klokkevold P, Carranza F. Carranza's Clinical Periodontology. 12th Ed. Philadelphia: Saunders-Elsevier; 2014. pp. 7482, 98-100, 991, 666-7

5. Ibrahim DS, Abd El-Maksoud MAE. 2015; 96(2): 87-93. DOI: $10.1111 /$ iep. 12116

6. Sitorus TE, Purwaningsih S, Wahyunitisari MR. Antibacterial effect of strawberry (Fragaria $x$ ananassa) extract on pathogenic serotype 1-11 Escherichia coli revealed using dilution method. Folia Medica Indonesiana. 2012; 48(4): 167-73.

7. Beuchat LR, Farber JM, Garrett EH, Harris LJ, Parish ME, Suslow TV, et al. Standardization of a Method To Determine the Efficacy of Sanitizers in Inactivating Human Pathogenic Microorganisms on Raw Fruits and Vegetables. J Food Protect. 2001; 64(7): DOI: 10.4315/0362028X-64.7.1079

8. Tintasari D, Wibowo TB, Nuraini P. Level Streptococcus mutans in salivary children after rinses Fragaria vesca L (Strawberry) infuse and Povidone lodine mouthwash. Indonesian Ped 
Dent J. 2013; 5(2): 20-24.

9. Pramesti A, Jasrin TA, Hidayat OT. Teeth re-whitening effect of strawberry juice on coffee-stained teeth. Padjadjaran J Dent. 2013; 25(1): 15-20. DOI: 10.24198/pjd. vol25no1.15427

10. Peerajit P, Chiewchan N, Devahastin S. Effects of pretreatment methods on healthrelated functional properties of high dietary fibre powder from lime residues. Food Chem. 2012. 132(4): 1891-8. DOI: 10.1016/j. foodchem.2011.12.022

11. Fajriani, Mahrum. Effectiveness of Lime (Citrus aurantifolia) Extract Solution in Inhibiting Bacteria Streptococcus Mutans Case of Early Childhood Caries. Donnish J Dent Oral Hygiene. 2015: 1(4); 16-20.

12. Oikeh El, Omoregie ES, Oviasogie FE, Oriakhi K. Phytochemical, antimicrobial, and antioxidant activities of different citrus juice concentrates. Food Sci Nutr. 2016; 4(1): 103 9. DOI: $10.1002 / \mathrm{fsn} 3.268$

13. Al-Oqaili RMS, Khudhr S, Al-Alak, Al-Fraji BBM. Antibacterial Activity of Citrus Juices against Methicillin Resistant Staphylococcus aureus. J Biol Agriculture Healthcare. 2014; 4(7): 7-10.

14. Takaya $Y$, Kondo $Y$, Furukawa $T$, Niwa $M$. Antioxidant Constituents of Radish Sprout (Kaiware-daikon), Raphanus sativus L. J Agric Food Chem, 2003; 51(27): p. 8061-6. DOI: $10.1021 / \mathrm{jf0346206}$

15. Yin N, Ma W, Pei J, Ouyang Q, Tang C, Lai L. Synergistic and Antagonistic Drug Combinations Depend on Network Topology. PLoS One. 2014; 9(4): e93960. DOI: $10.1371 /$ journal.pone.0093960

16. Tulipani S, Mezzetti B, Capocasa F, Bompadre $\mathrm{S}$, Beekwilder J, Ric de Vos $\mathrm{CH}$, et al.
Antioxidants, Phenolic Compounds, and Nutritional Quality of Different Strawberry Genotypes. J Agric Food Chem. 2008; 56(3): 696-704. DOI: $10.1021 /$ jf0719959

17. Oviedo-Solís $\mathrm{Cl}$, Sandoval-Salazar C, LozoyaGloria E, Maldonado-Aguilera GA, AguilarZavala H, Beltrán-Campos V, et al. Ultraviolet light- $C$ increases antioxidant capacity of the strawberry (Fragaria $x$ ananassa) in vitro and in high-fat diet-induced obese rats. Food Sci Nutr. 2017; 5(5): 1004-14. DOI: $10.1002 /$ $\underline{\mathrm{fsn} 3.487}$

18. Kumar S, Pandey AK. Chemistry and Biological Activities of Flavonoids: An Overview. ScientificWorldJournal. 2013; 2013: 162750. DOI: $10.1155 / 2013 / 162750$

19. Cushnie TP, Lamb AJ. Antimicrobial activity of flavonoids. Int J Antimicrob Agents. 2005; 26(5): 343-56.

20. de León L, López MR, Moujir L. Antibacterial properties of zeylasterone a triterpenoid isolated from Maytenus blepharacles against Staphylococcus aureus. Microbiol Res. 2010; 165(8): 617-26. DOI: 10.1016/j. micres.2009.12.004

21. White NJ. Pharmacokinetic and Pharmacodynamic Considerations in Antimalarial Dose Optimization. Antimicrob Agents Chemother. 2013; 57(12): 5792-807. DOI: $10.1128 / \mathrm{AAC} .00287-13$

22. Chandrasekar V, Knabel SJ, Anantheswaran RC. Modeling development of inhibition zones in an agar diffusion bioassay. Food Sci Nutr. 2015; 3(5): 394-403. DOI: 10.1002/fsn3.232

23. Tortora GJ, Funke BR, Case CL. Microbiology: An Introduction. 11th ed. San Fransisco: Benjamin Cummings; p. 1-80. 